\title{
Fungus Diseases of Papaya in the U.S. Virgin Islands'
}

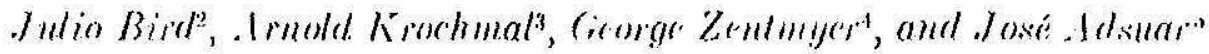

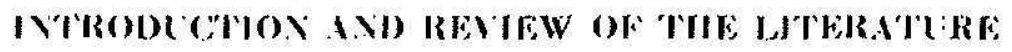

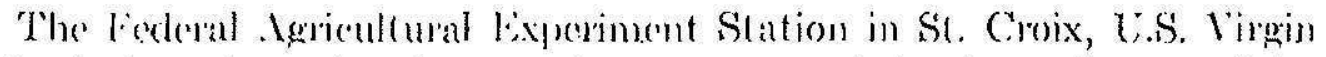
Islands, has, since 19it, been lesting panplya variedies from all parts of the wopical wortd.

In 19:5) a disense was olserved allateking several varietics. Willersonked areals on the unpere lovels of the stem were observed on all alfereded papaya plants. These areat often appera greasy rather han wet (fig. 1). The disetase has been denominated "greatsy spot," and "piulaya dereline."

In Hawaii, Bembower (2) observed water-soaked spots on the stems of papaya, and determined them to be caused by Phylophthora parasilica.

After (omparing the symptoms found on papayat plants in SI. ('roix with those described from Hawili, the writers concluded that the discrises were different. In Hawaii, the fruits berome affected (fig. 2) and eventually shrivel and drop to the ground. Surh is not the case in St. Croix.

Samples of roots take'n from 'Solo' paluaya plants displaying the sem lesions were sent by air to the Yniversity of ('allifornia, Riverside, on several oc'atsions, but uo Phylophthora species were isolated. Papaya dectine was one of the major "auses of lows of benting trese during 3 years of ficldwork in st. Croix (8).

In the suring of $1963 \mathrm{~W}$ (cllman (12) reported that there wis a leat spot discise ou lluese 'Solo' plants probably caused hy ('ercospora. The symploms of disease observerl in the Virgin Islands are different, however, from those reported as caused by ('ercospora in Harraii (f).

Besides the aforementioned walcr-soaked spots or greasy spots, the followiug symptoms shatreterize the St. ('roix disciase:

The foliage of affected plants apprams seatul, rigid, and gencrally shlorotic:

1 The authom wish to ackurowedge financial assistance provided hy the Carbbean Food Cons rociely and the it. Croix Cirouers dssociation.

${ }^{2}$ Head, Department of Phat Pathology and Bulany, Agrieultural lisperiment. Station. Ciniveraty of Puerto liko, Rín Piedrats, P.R.

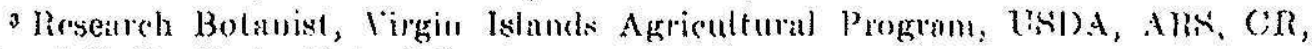
Kingshill, St. Croix, L...., V.1.

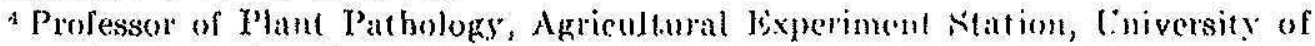
California, liverside, Cirlif.

"Plant Pafbologist, Agricultural Pixperinent it:tion, Cuiversity of Puerto Rico. Río P'icelras, P'L.

"Italic numbers in parntheses reler (o Siturature Citnd, p. 200. 


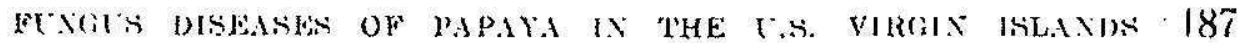

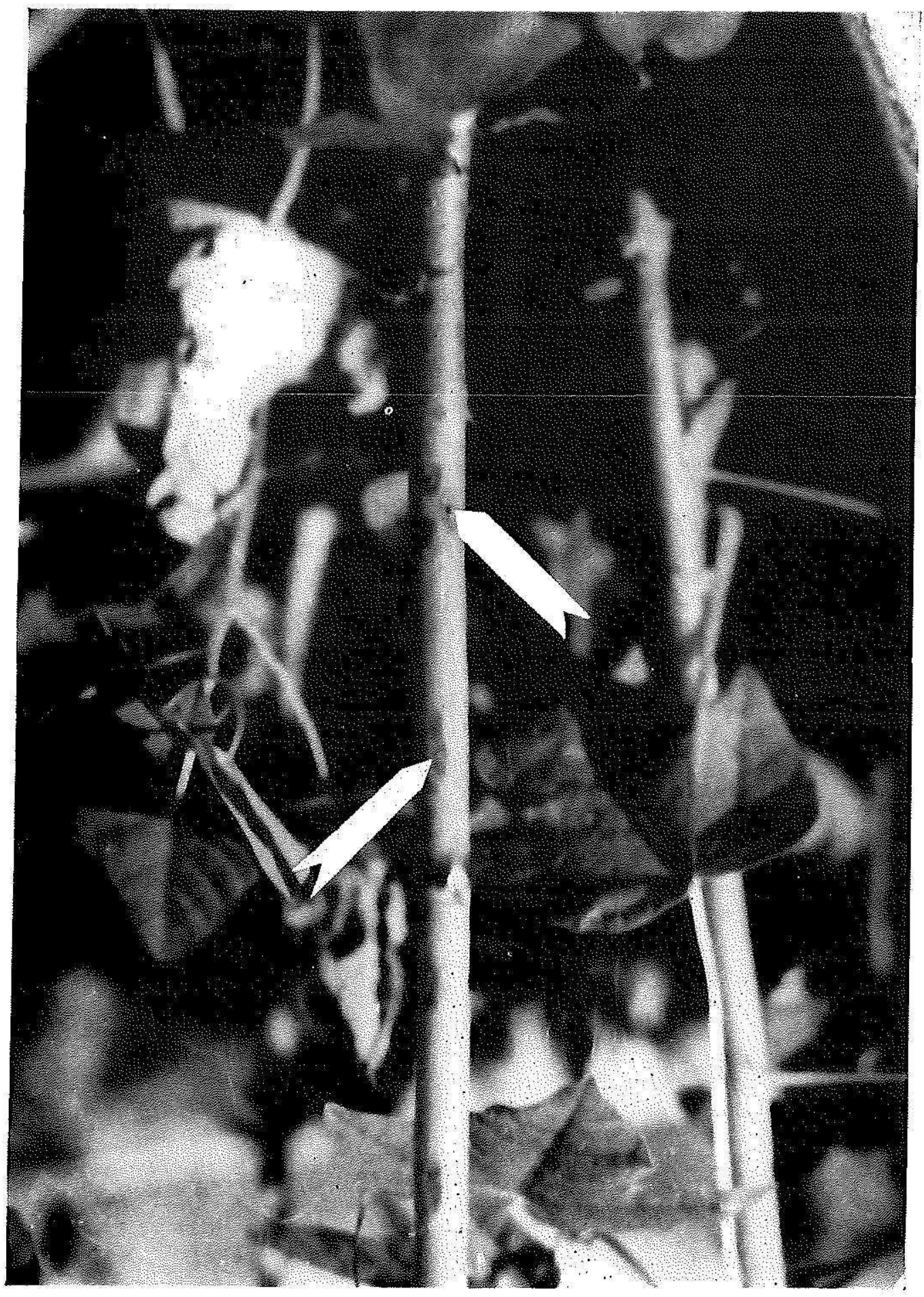

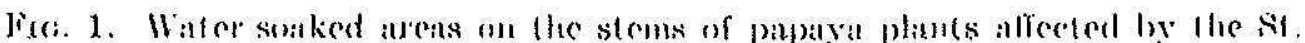
(roix discases. 
Discased plants dovelop ath umbrollalike shat)e (fig. 3) which resembles (lat associaled with papaya butely top $(3,4)$, but dese ohservation shows that this disease is not related to bunehy fop sines:

1. Tatex issues from the fissues of plauts alfeeted by the St. (iroix discascis.

2. The loufhopper vector of butuhy top, limpoasca papayae, has not been

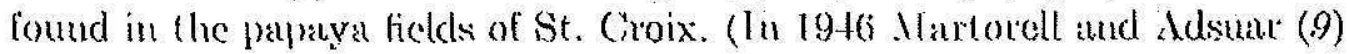

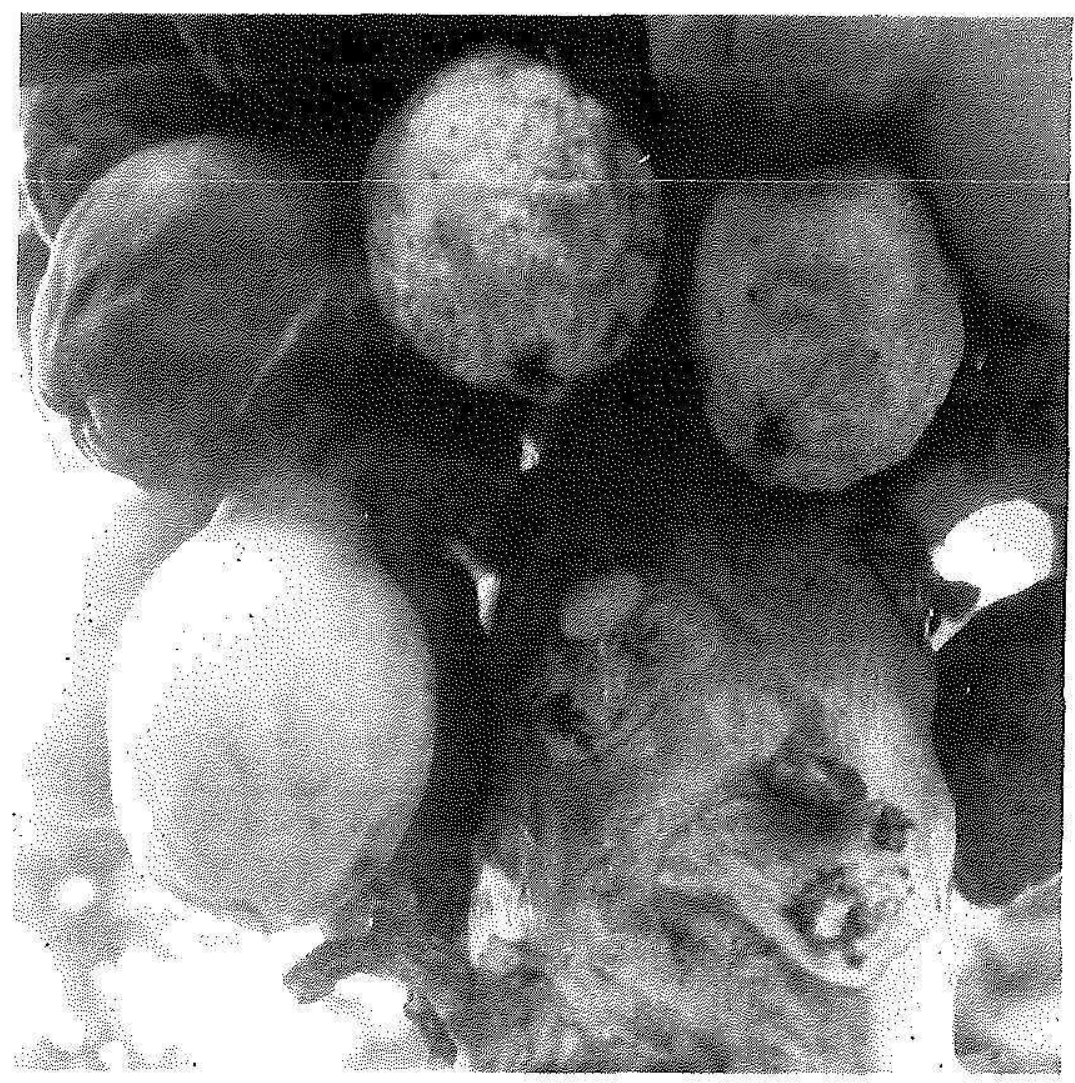

lis. 2-Fruit of c'arica papaya allected by Phylophthora parasitica.

did collect an apparenly new species of Eimpoasca breding on papaya in St. (roix.)

3. Symptoms of the lwo discases differ in many other respects.

In the field the lower leaves of affected plants are dotted with yellow spots (fig., f) which range iu sime from just visible to ats latge at a vilver

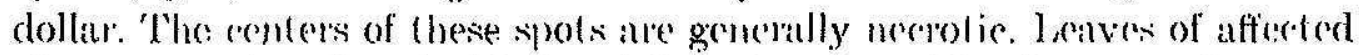
plants ane offen found dried and hanging alongside the stem. In some instaneses, it the ped jole is detached from lhe stem, moist, amkeroms lesions anc $(x p)$ osided.

This suggests that the leat-spotting agent gains aceess 10 and infert:- 


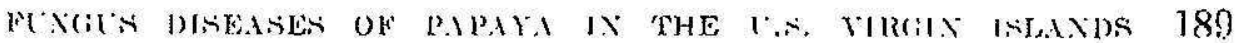

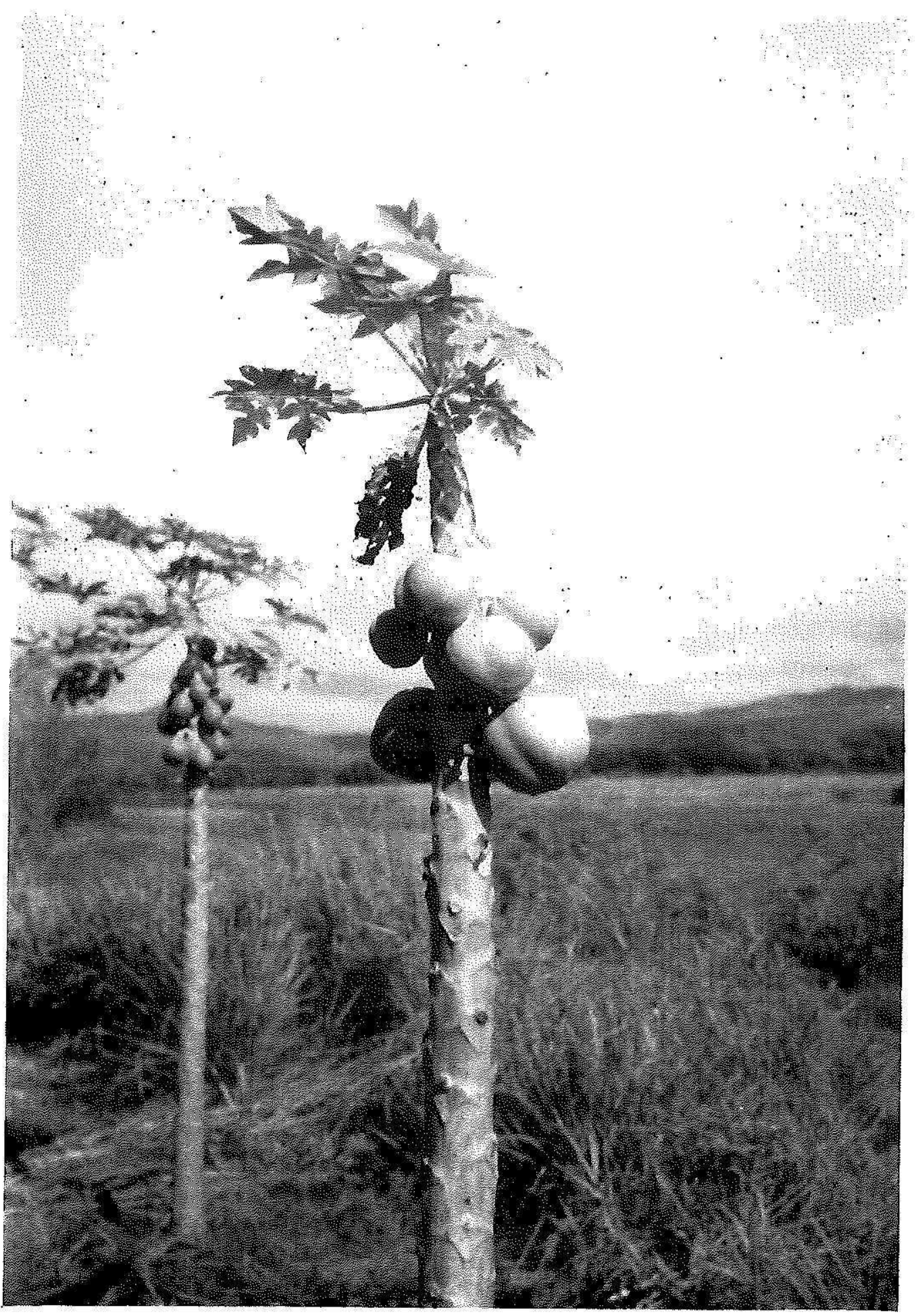

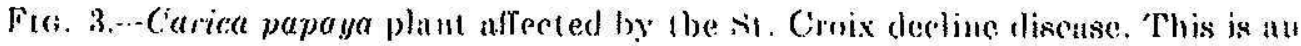
idvanced case of the malaly with typical "peuril-point" oftert. 
stem listore. In many of the plants with the amkexous loxions, the lower

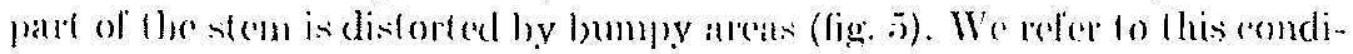
lion as "bumpy stom." Bumy sections are not loumd on the sioms of all the phats with a redued camopy and of here symploms of the dimestse.

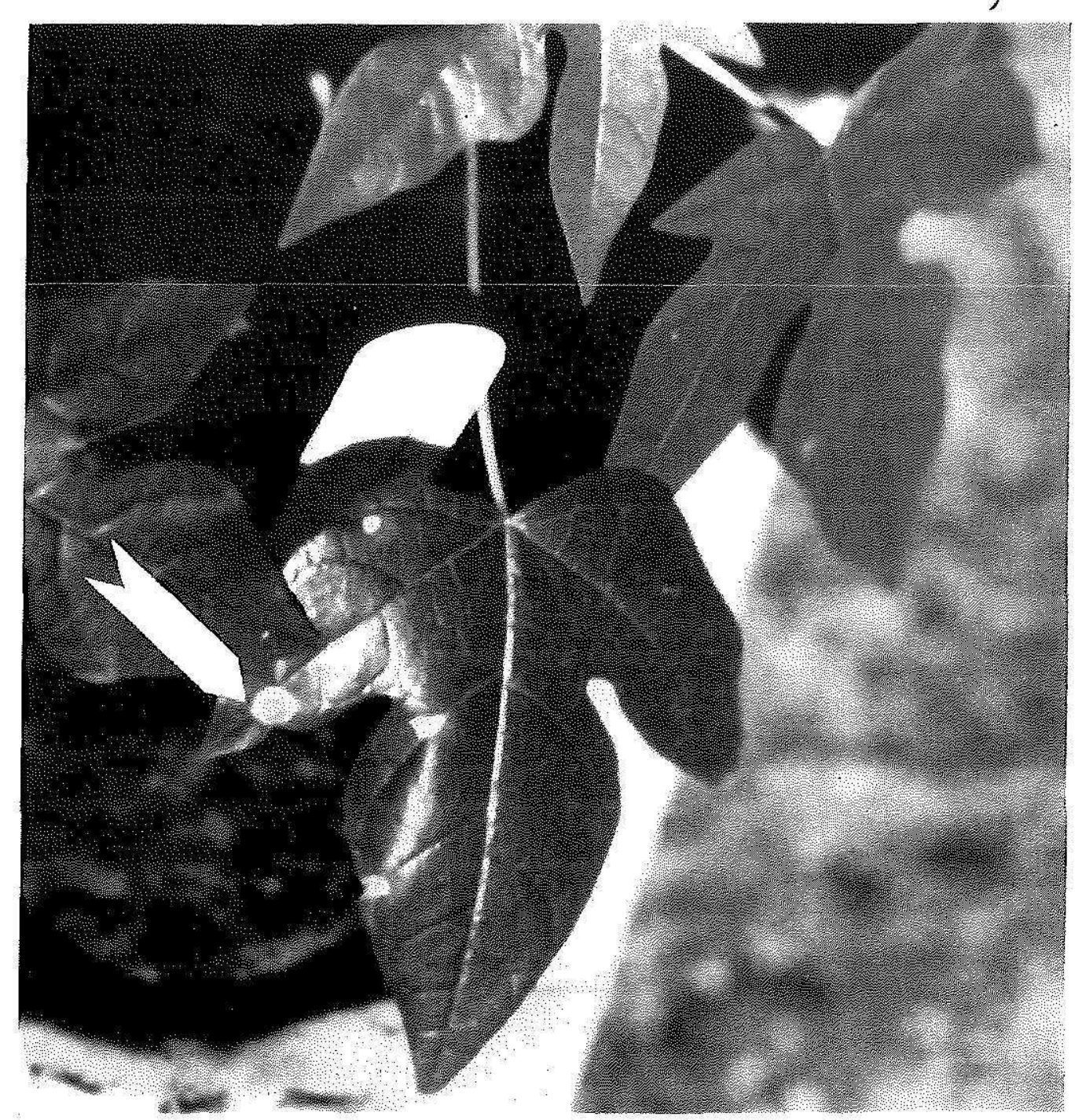

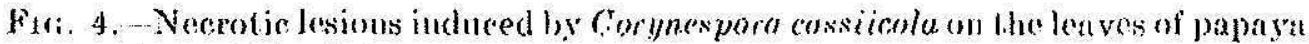
plantse of the variety 'sulo'.

A possibly different ring sjotting, ats well as curling of the laves, was obrorved in several plantutions. None of these symptoms rould be asisoriated with those of any of the virts discases that oceur in the c'aribbean a1m:

some of the native (Cruman) payay plants we rolatively lice of leaf syol-; but in some individual ases the malady is severe. The mative papayas 


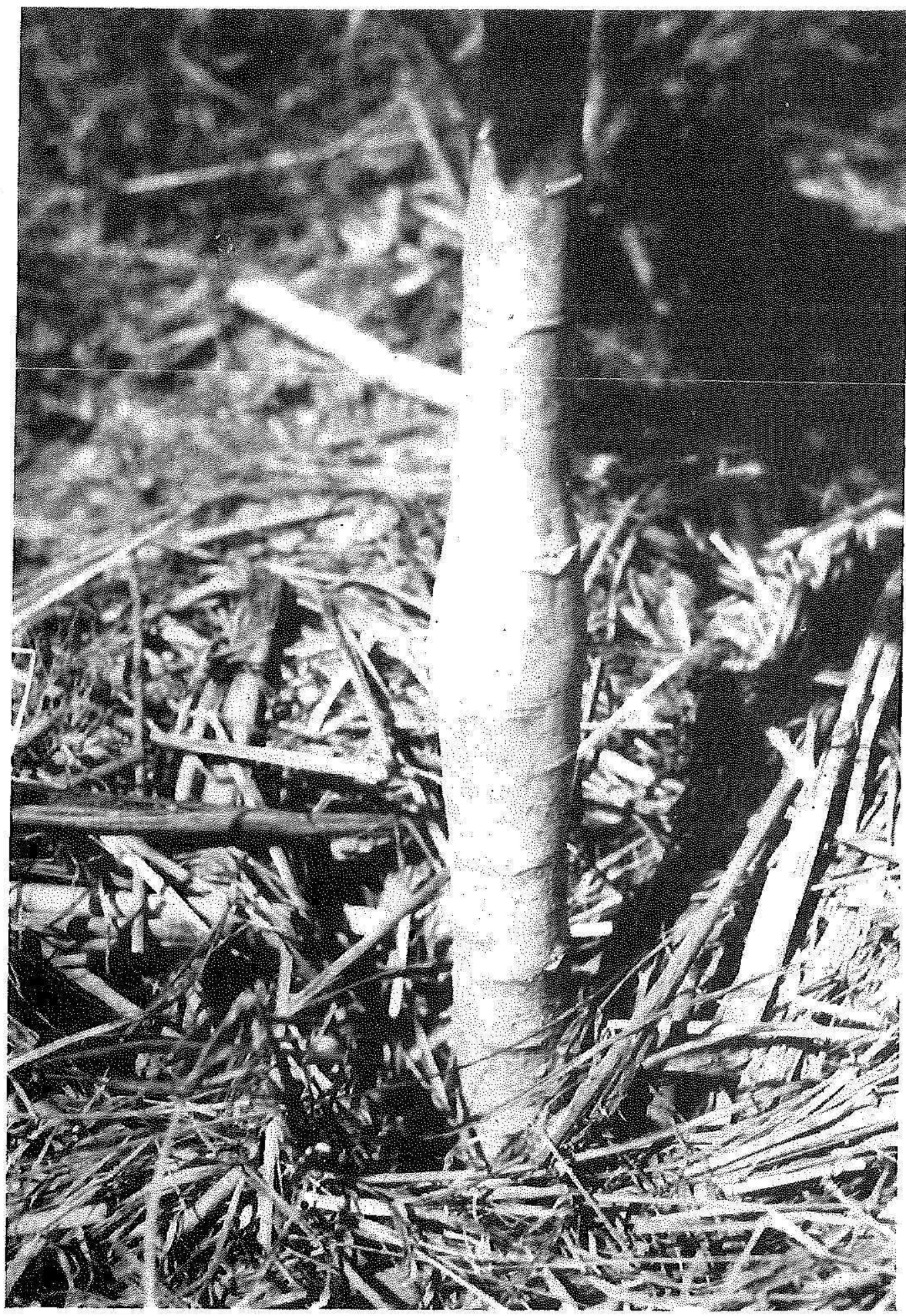

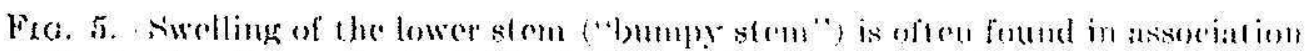

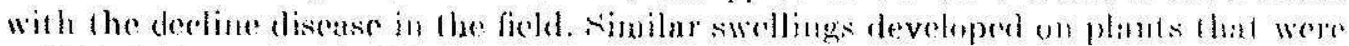
artilieially inoculated with ('orymespora rassiteoln. 
akn becone afforted by the bumpy stem roudition but seem ith general not to be greatly jujued by it.

\section{(OB.JW:TIVIS}

Paphay fruts of the 'Solo' type are in great denund in the Miani, Vow lork, and sim fum makels. However, rerlain vilus and fungus disetses limit. the production of 'Solo', as well as other papaya varietics, in the West Indies. Paphay decline is a very serious disease in some of these islands. It was decided to molertake work ou this malady in an attempl ro eluevdate its eliology, and also to develop mesus for its control.

\section{ISOIIATON AND JNOCULATION STIIDLS}

\section{ISULATION SIUDJk}

Sipcomens lrom lesioned arras of the stems and from leat spot-affected, ruted, and ring ipolferd leaves were collected from valious lields in St. Croix, washed with bywat ex and placed in polycthylene bags. The material was divided, and purt was plated on acidificd PDA after surface disinfertion with (Jorox ( l. $\left._{20}\right)$. Another bateh was used for inolation of barteria, and a third-with curled and liug-spolted leaves, was ground in order to secure say for mechanical inorulation of various plant hosts. . Yo bacteria could be isolaterl from afferted stem or foliage tissues. A series of test plants belonging to several families and including such suecies as: Carica papaya ('Solo', Cruzu, and Pucrto Rictu varict.jes), Phylolacca decandra, ('henopodinum amaranticolor, ('apsicum annum, Nicoliana labacum, Nicotiana

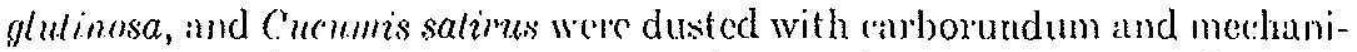
(ally inoculated with the sal) expresised from eurled and ring-spotted latves. 'l'm plants of each of the atorementioned speries and varietics were inorulated in cach of two treatments and observed daily for a perjod of 3 months. Fone of these plants developed symptoms of discase, thus indienting that no merbanically I manmissible virus is associated with the St. Croix diseatse.

The lesjoned tirsues from the upper parts of the stem, as well as spot ted areas from the loaves yielded several fungi on acidified (j) $\mathrm{H}$ j) protatodextrose agur. This included speries of Fusarium which wore disculded as rontanumats since they reprextuted a very minor perentage of the isolat es in contrast with a fomgus thall arose from about 90 pereent of the plated lissuc bil: 'l'his has fumgus was shumeterized by a cottony, gray mycolial growth, which chatged the eolor of the substratume trom light raramel to datk brown and even to jal blate. Mficrosepric examinalion of bits of

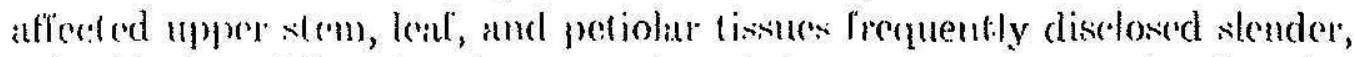

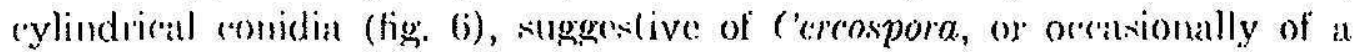

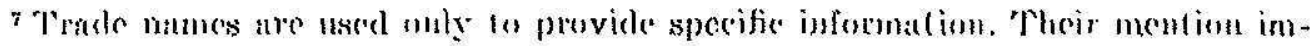
plics no gruarnulee. warranty, ar endersement by llue station. 


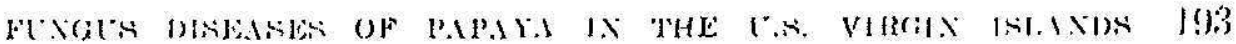

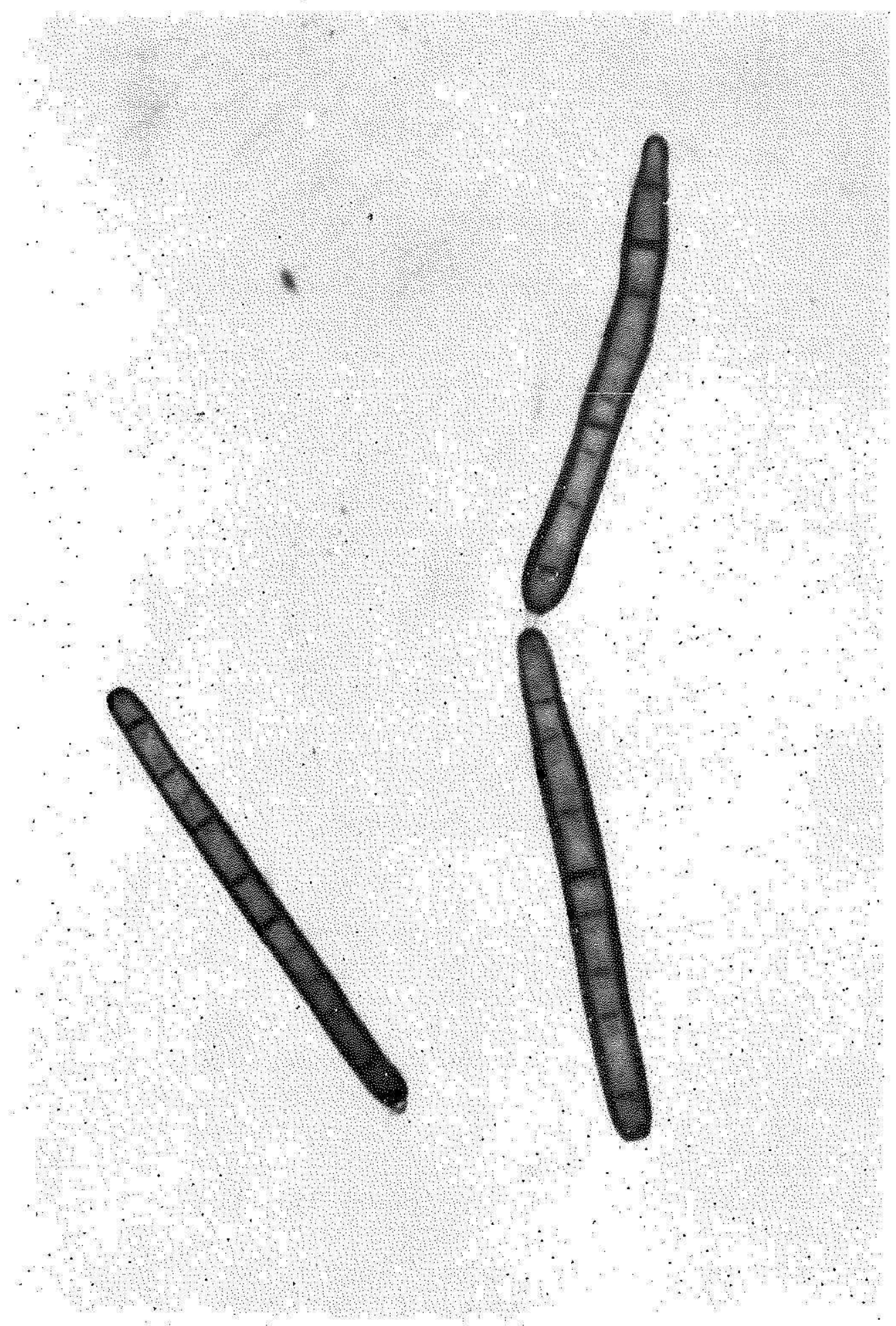

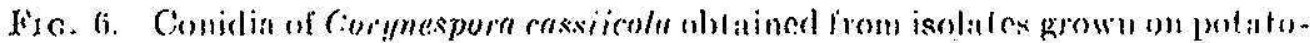
dext rose agatr. 


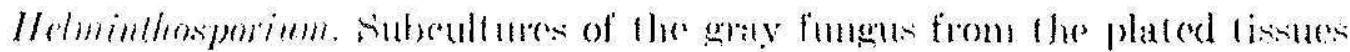

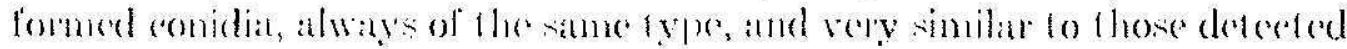

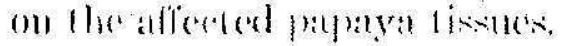

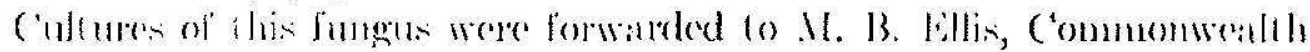

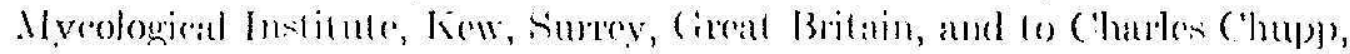

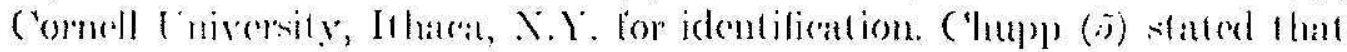

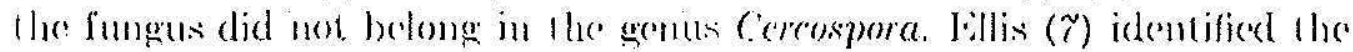

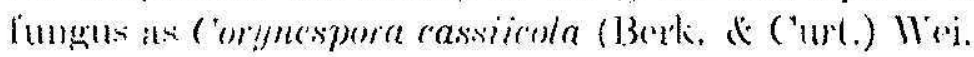

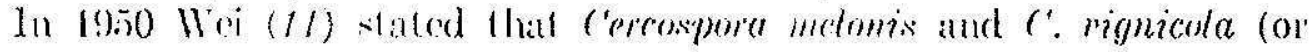

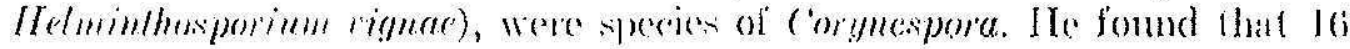
rollection: on $1 /$ hosts from the Tropies, peviously identidied as Helmintho-

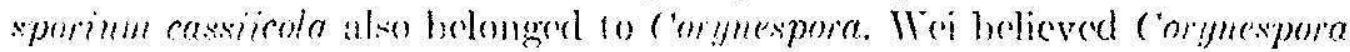

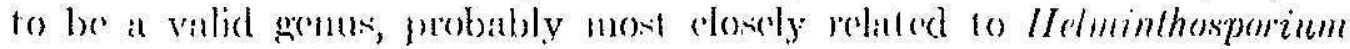

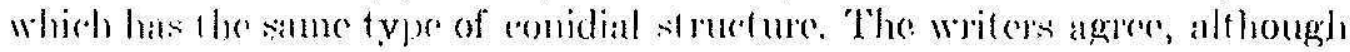

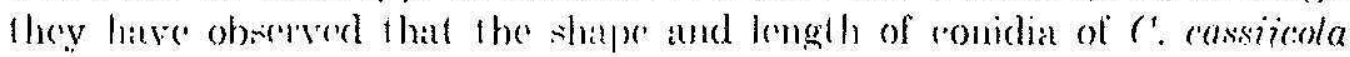
was somewhat vamiable. Coniclia formed on papaya plants ate gencrally large, slouder, and light olive in color, and at limes almost hyaline. Those produced an aridified PJ)d by lhe simme fungus are genemally cylindrical and thicker, their color ranging l'rom light-brown to datk brown. In the first ense the endia look mather like those of ('ercospora, while in the sereond they are more stgegestive of Helminthosportum. There is no cquestion, however, as to the validity of Eallis' identification of om coltures. Deserip)lions of the fungus are given by IVri $(/ I)$ and lillis $(j)$.

MORTHATON STIMTES

\section{Inoculations: will r'. crassiimola.}

Mycelial mats of ealtures from the same isolates that were forwaded lo billis, were suspended in streile distilled watere This mal erial was homoge-

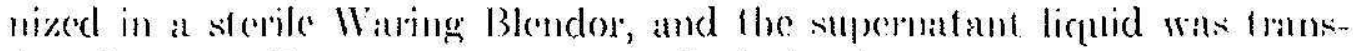

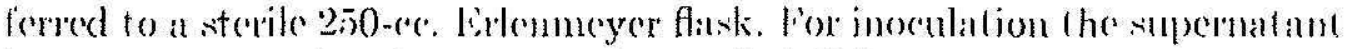
liguor was stired and transfered to a Derilbliss No. Lijl allomizer. The stivernsion wats impelled by air at 20 pounds p.s.i. and diresed from a distance of approximately 1 foot to the foliage and stems of the fest plants. Six lomolect healthy 1 -foot 'Solo' papaya plauts growing in six different flats wew inoculated in the deseribed manuer. After the plants were inosulated the flats were tmustered to a moist rhamber and kept at 90- to 100 -pererent reative humidity. I set of 100 cont rol plants growing undex the same conditions were sprayed with serpile distilled water, and then tausfored to a chamber that was also kept at the same rolative humidity

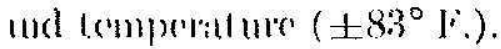

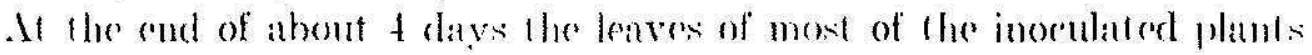


developed small, round, yellowish waler-soalied arras, These spols were

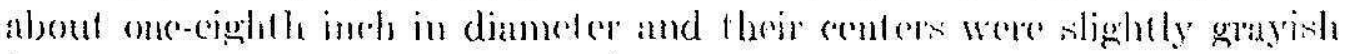
in rolor, suggesting tisine breakdown. 'The surenlent green parts of the

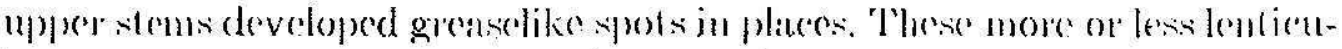

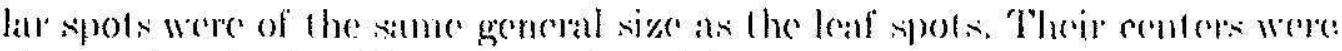

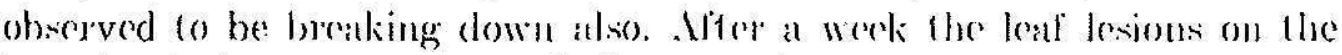
inoculated plants berame visibly latwere and, in some "ases, enaleserne' of lesions resulted in the breatidown of entire lenves. Nerosis was atso evident on the perioles and lower parts of the stems of some inowaldod plants. The: older upper-stem lesions were gimmy, and many of them more eroded at this time. The cont rol phants remained heallyy throughout this terst.

.11 the end of 8 days the romtrol and fost plante mete taken out of the

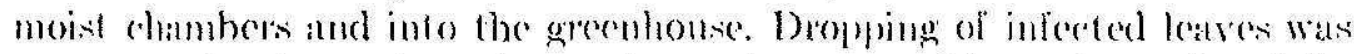
rommon. If limes these humg along the stom without beesoming fully abseised. The spots on the lateses and the water soaked ateas of the sten were like those encountered in the fickd. As the and of thout I month most of the inoculated plants hat lost their lower leaves with only four or live

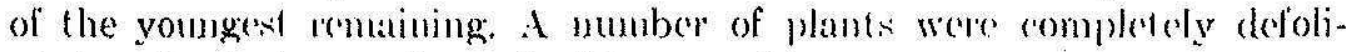
aled, and apical neresis resulled in several instanees.

'two months later conditions in the greenhouse berme extremely dry, a number of plants matkedly imporoved, and some lost all symptoms of

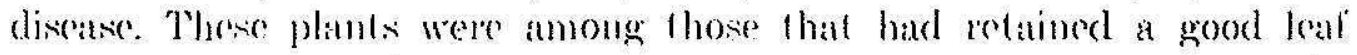
("inolyy.

One week, fwo wereks, there weeks, and one and a ball monthe after inoculation, C'orynespora was recovered from scm, leaves, and periolas lesions of the artificially inoculated plants. ("ultures thus oblatiod (fig. T) were found to be identionl with the original isolate.

There monthe atter inoculation some of the "reerovered" plants were found to be still vigorous and healthy, while others showed litte or no mogress. Many of the artificially inoculated plants with lesions on theit lower sems had developed, at this stage, sizmble bumps, Similar results wrere obtained in a serend lest using suberultures from the original isolates.

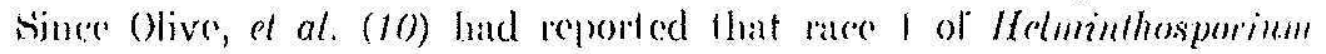

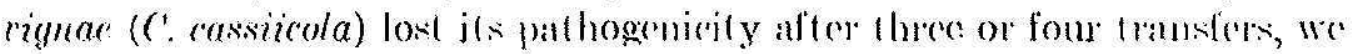
reperted the tests described above, using the same isolates at er four transJers on acidified PD.d. Not a single papaya plant developed symptoms of discate; this beyond doubt shows that virulener was lost on thanderving this organism in the medium nsed.

\section{Inoculations wilh Botryodiplowlia}

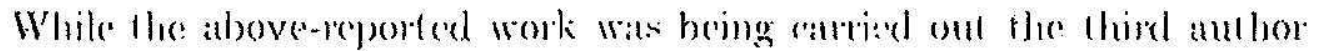

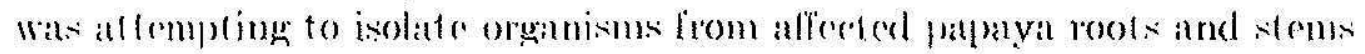




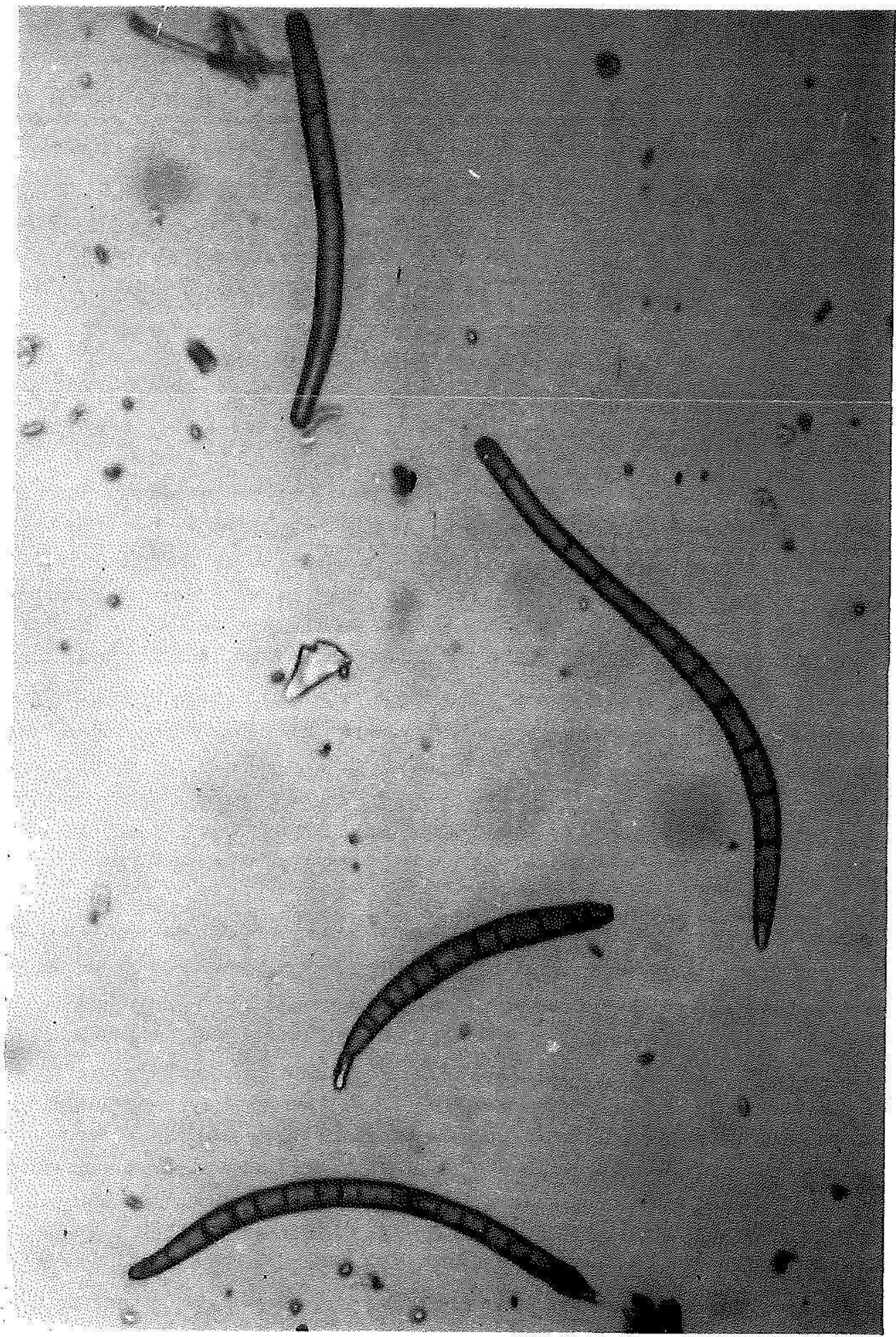

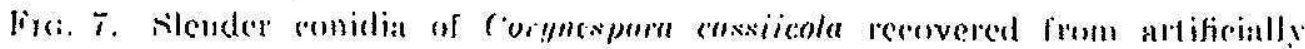

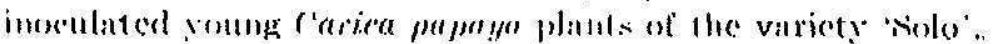




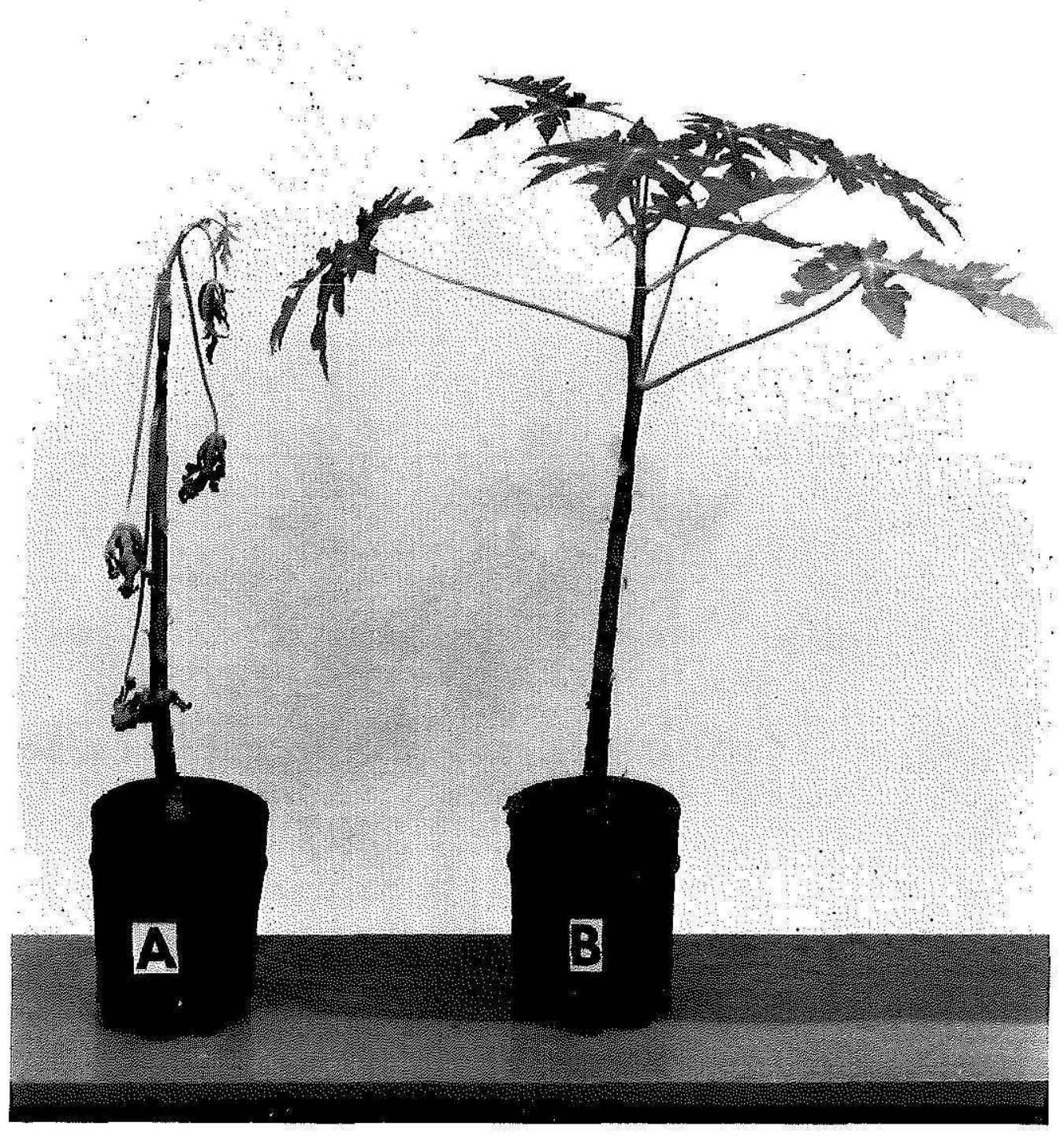

Fig. 8--A, Seven-momth-nd papaya seedling of the varicty solo attificially inorulated with PJ)A disks eonlaining $24-$ hour-old cullure of the isolate (Si) 4 ) of Bot-

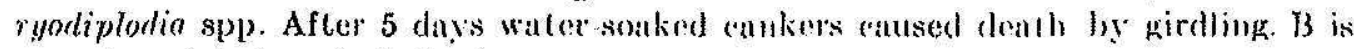
an uninuculated cont tol planl.

forwarded by air to California. The lirst samples yielded several fungi, including a species of Pythium. However, uone of these organisms was consistently atsisoriated with the lesions. Simples received subsequently from st. Croix yiclded a fungus with dark mycritum and dark 2-celled 


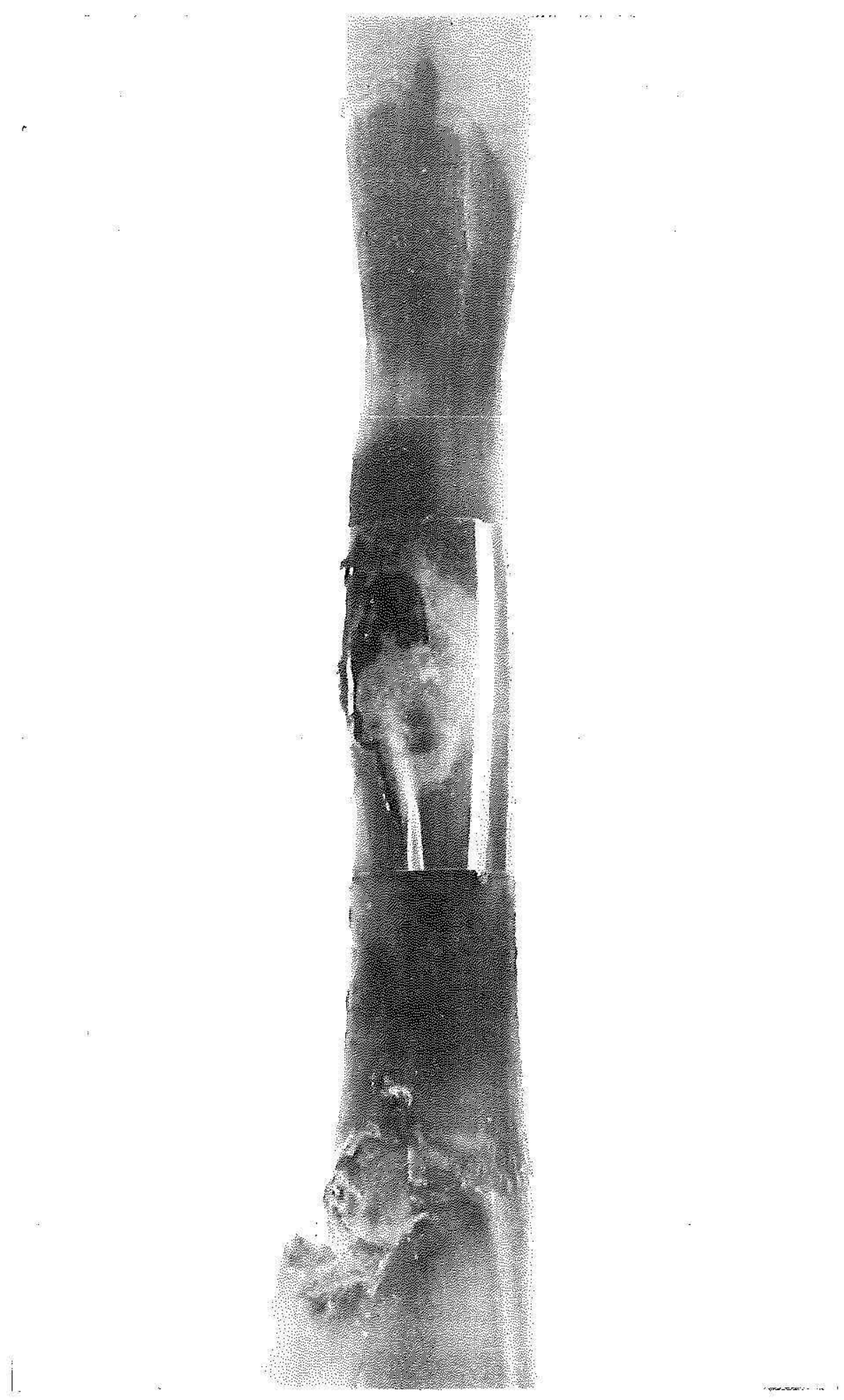

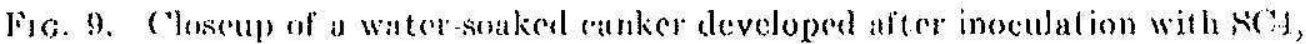
Botryerliptodia. 
conidia. This fungus, a speries of Bolryodiplodia, was consistently isolated from water-soaked stem Iesions. It formed mmerous py enidia on the lrunks of affected papaya plants.

Inoculations of small (12 to 18 inches tall) papaya seedlings ('Solo' varicty) in the greenhouse at Riverside, Calif., with myeclium of the Botryodiplodia isolated, resulted in severe necrosis of stems (figs. 8,9) within a week after inoculation. The same fungus was reisolated from the lesions.

\section{DISCUSSION}

It appears to us that most of the symptoms of the papaya-decline syndrome were reproduced under coulrolled conditions in Puerto Rieo by inoculation with Corynespora cassizcola.

C. cassivela is a highly pathogenic organism, although it loses its virulence after series t runsfers through artificial media. In St. Croix it em be a dangerous pathogen in papaya orchards receiving poor rare. Manzate D) gives salisfactory control if applicd every week or 10 days at the rate of $11 / 4$ pounds per 50 gallons of water. There is suggestive evidence that there may be heritable factors for resistance. A good many wild papaya plants show no symptoms, and old uutended 'Solo' orchards usually have a scattering of trees that remain vigorous and fruitiul, even though they have light infections of Corynespora on the leaves. Selections from such plants are now under observation at the Federal Experiment Station, St. Croix, U.S. Virgin Islands.

It is not known with edainty what role Botryoliplodia may be playing in the papaya decline syndrome. It is possible that many of the moist cankers that have been at ributed by us to Corynespora may actually have been induced by Botryodiplodia. Further rescarch is needed to elucidate the etiology of the soft cankers of papaya plants in St. Croix.

\section{SUMMARY}

Corynespora cassicola (Berk. \& Curt.) Wei, and a speries of Bolryodiplodia were consistently isolated from various tissues of Carica papaya plants afiected by the parayn decline disense. Ioung papaya plants of the 'Solo' variety were succossfully inoculated with the aforemontioned fungi. Most of the symptoms of the decline discase developed on papaya plants after inoculation with Corynespora. Severe stom neerosis of papaya plants resulted from inoculation with Botryodiplodia. C. cassizcola loses its virulence after serios transters through artificial media.

\section{RESUMEN}

Se logró reprodueir la nuyoría de los síntomas del mal común de la papaya de Santa Cruz después de inocular plantas de papaya de la variedad 
'Solo' con ol hongo Corymespora cassizola (Bork. \& Curt.) Wei. So produjo una severa neerosis del tallo ruando se inoculó la mencionada variedad con una especie de Botryodiplodia. C. cassizena pordió su virulencia al transferise on sorie, en un cultivo artificial.

\section{HTERATURE CITLD}

1. Arisumi, Tom, Test shipments of Papayns, Hawaii Agrieultual Experiment Station Tech. Bul., Jan. 29, 1956.

2. Berbower, Wm., Papaya Cnlture, Hawaii Lxt. Cire. 234, Apr. 1952.

3. Bird, J., and Adsuar, J., On the Viral Nature of Papaya Bunchy Top, Phylopath. (abstr.) 促(3): 1952 .

4. - and - - , Viral nature of papaya butchy top, J. Agri. Univ. P.R. $36(1)$ : $5-11,1962$.

5. Chupp, Charles, personal communieation.

6. Ellis, M. B., Some Species of Coryuespora, Mycological Papers No. 65, Commonwealth Mycol. Inst., Kew, Surey, England, Jan. 1957.

7. Ellis, M. 3., personal communication.

8. Krochmal, Amold, and Frederiksen, A. T., Yield eomparisons of interior and border Plants in papaya (iroves, Proc. Caribben Region, A.S.H.S. vol. 6, Dec. 1962.

9. Martorell, Luis $\mathrm{F}^{2}$, and Adsuar, J., Insects associaled with papayil virus disenses in the Antilles and Forida, J, Agri. Cmin. P.R. $36(4): 319-29$, Oct. 1952.

10. Olive, L. S., Bain, I). C., and Lelebvre, C. T., A leafspot of eowpen and soybean caused by an undescribed species Hetminhosporium, Phylopath. 35: 822-31, 1945.

11. Wei. C. T., Notes on Corynespore, Myeological Papers No. 34, Commonwealth Mycol. Tust., Kew, Surrey, Tengland, Aug. 1950.

12. Welman, Froderick, Disease Problems of Papaya in St. Croix, (unpublished report). 